\title{
Comparative Geochemistry of Volcanics from Rift Valleys, Transform Faults and Aseismic Ridges*
}

\author{
Roger Hekinian ${ }^{1}$ and Geoffrey Thompson ${ }^{2}$ \\ ${ }^{1}$ Centre Océanologique de Bretagne, B.P. 337, 2973 Brest, France \\ ${ }^{2}$ Woods Hole Oceanographic Institution, Woods Hole, Massachusetts, U.S.A.
}

\begin{abstract}
New chemical analyses and a review of published data show that there is a compositional diversity between volcanics of basaltic composition found in the M.A.R. rift valley, M.A.R. transform faults and aseismic ridges. The basaltic rocks from the M.A.R. transform faults are less mafic (depleted in olivine content) than those from the M.A.R. rift valley. The transform fault basalts have a higher range of $\mathrm{TiO}_{2}$ content $(1-4 \%)$, of $\mathrm{Fe}_{2} \mathrm{O}_{3}+\mathrm{FeO}$ content $(8-14 \%)$ and a lower range of $\mathrm{Cr}$ content $(50-500 \mathrm{ppm})$ and $\mathrm{Ni}$ content $(50-300 \mathrm{ppm})$. The volcanics from aseismic ridges around the world are considered to be the more felsic types of the two provinces. They have a higher range of variation for their $\mathrm{TiO}_{2}$ and $\mathrm{Fe}_{2} \mathrm{O}_{3}+\mathrm{FeO}(1.6-5 \% ; 9-15 \%$; respectively) and a lower range of variability for their $\mathrm{Cr}$ and $\mathrm{Ni}(<250$ and $100 \mathrm{ppm}$ respectively) than both the M.A.R. rift valley and transform fault volcanics.

It is suggested that transform faults have, by faulting, exposed more fractionated types of basaltic rocks (may be as intrusives) than the rift valley volcanics. While aseismic ridges have undergone a greater degree of differentiation than both transform faults and rift valley volcanics.
\end{abstract}

\section{Introduction}

Mid-oceanic ridges, fracture zones and aseismic ridges are among the main tectonic features of the world's oceans. These particular structures are important in understanding the plate tectonic mechanisms and the genesis of the oceanic lithosphere. The purpose of this study is to review and compare the volcanics of these major oceanic provinces. Mid-oceanic ridges are the loci of the divergence between two (or more) plates, and it is now proved that the inner floor of the Rift Valley is the point of the most recent and abundant volcanic activity

* Contribution $n^{\circ} 475$ du Département Scientifique, Centre Océanologique de Bretagne Contribution No. 3803 of Woods Hole Oceanographic Institution (USA) 
(Bellaiche et al., 1974). It is also now known that various types of lava are brought to the surface in the Rift Valley (Bellaiche et al., 1974; Arcyana, 1975; Ballard et al., 1975).

According to Wilson (1965), fracture zones represent the motion of a plate in the crust in relation to others, and most probably recent volcanic and tectonic activity occurs in the transform area. Up to now, most samples of oceanic rock described in the literature were collected from fracture zones in their transform areas. Major compositional variation between transform faults and recent spreading ridges associated with the Rift Valley have been attributed mainly to the presence of ultramafics and metamorphics in fracture zones; little attention has been given to the volcanics of a less mafic nature or to unaltered rocks in both regions. Some authors (Honnorez and Bonatti, 1970; Thompson and Melson, 1972; Melson et al., 1967) have reported the presence of recent volcanism of an undersaturated character in the Romanche Fracture Zone and on St. Paul's fracture zone.

Aseismic ridges are chains of elevated volcanos which are the surface expression resulting from plates moving away from fixed hot spots in the mantle (Wilson, 1965; Morgan, 1971, 1972). The Ninetyeast Ridge (McKenzie and Sclater, 1971), the Walvis Ridge (Francheteau and Le Pichon, 1973), and the Cocos Ridge (Van Andel et al., 1971) show some tectonic characteristics of fracture zones, such as steep scarps and disleveled topographic contour lines between the adjacent basins. However it is difficult to assess if fracturing represents a primary feature on which elevated ridges were formed or if it is a post-constructional feature where faulting has been a secondary process associated with the build up of the ridges. Thompson et al. (1974) and Hékinian (1974) suggested that some aseismic ridges have volcanics which are different from those found on mid-ocean ridges.

In this paper we present comparative chemical data of volcanics from the mid-ocean ridges, fracture zones in the Atlantic and aseismic ridges. Figure 1 shows the sample locations in the Atlantic ocean. It is our intent to indicate that these different oceanic provinces have extrusive rocks with different chemical characteristics.

Fig. 1. Simplified bathymetric map of the Atlantic Ocean after Uchupı (1971). The numbers indicate the locations of samples used in the text. 91 indicates samples collected from the Rift Valley near the Charlie Gibbs Fracture Zone (Hekinian and Aumento, 1973); 92 and 93 are samples from the Charlie Gibbs Fracture Zone (Hekinian and Aumento, 1973; Campsie et al., 1973). 1 indicates samples from the Rift Valley near $50^{\circ} \mathrm{N}$ (Nicholls, 1965). 4-12 are samples from the Rift Valley near $45^{\circ} \mathrm{N}$ (Muir et al., 1964, 1966; Aumento, 1968). 13 indicates samples from a transform fault near $43^{\circ}$ N. 36 indicates samples from the Rift Valley and transform fault "A" near $36^{\circ} 50^{\prime} \mathrm{N}$ (Bougault and Hekinian, 1974). 30 are samples from the Oceanographer Transform fault (Shibata and Fox, 1974). 31 are samples from the flank of the M.A.R. (Kay et al., 1971). 38 are samples from the Atlantis Transform fault (Miyashiro et al., 1969; Muir et al., 1966; Kay et al., 1971; Shido et al., 1974. 40 are samples from the Rift Valley (Nicholls, 1965). 43 and 44 are samples from the Rift Valley (Miyashiro et al., 1969; Shido and Miyashiro, 1971). 49 are samples from the Kane Fracture Zone (Miyashiro et al., 1969). 59 are samples from the Rift Valley (Melson et al., 1969). 60 are samples from St-Paul Transform fault (Melson and Thompson, 1973). 61 and 62 are samples from the Romanche Transform fault (Bonatti et al., 1971) 


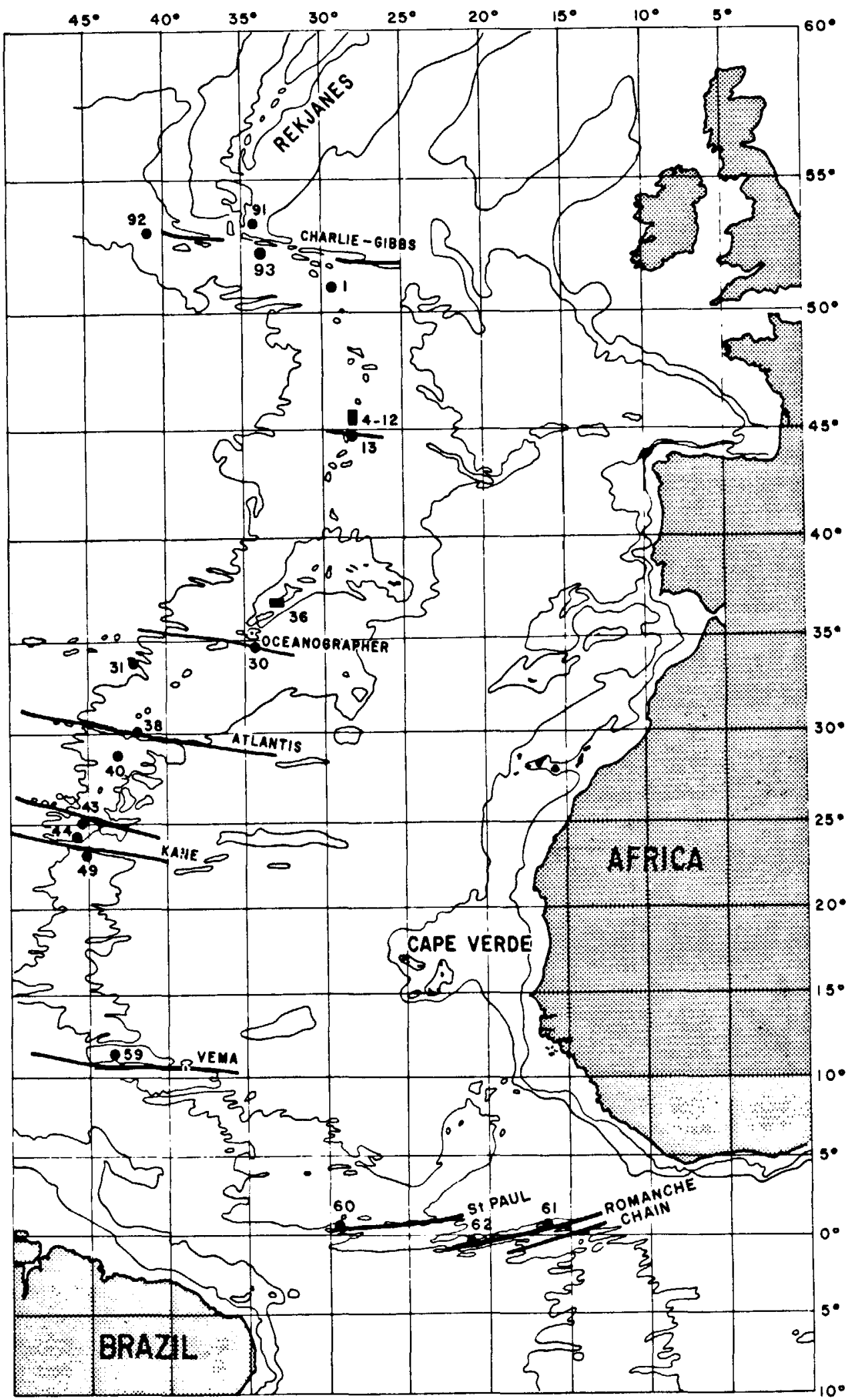

Fig. 1 


\section{Volcanics from Mid-Atlantic Rift Valleys}

The FAMOUS (French-American Mid-Ocean Undersea Survey) project has provided detailed and valuable information about different types of volcanics and their structural settings in the Rift valley. Thus the Mid-Atlantic Ridge (M.A.R.) near $36^{\circ} 48^{\prime}-37^{\circ} \mathrm{N}$ has become one of the most detailed surveyed portions of the world's mid-ocean rift system and the detailed petrological results from the FAMOUS area have been published elsewhere (Bellaiche et al., 1974; Bougault and Hékinian, 1974; Arcyana, 1975; Ballard et al., 1975; Bryan and Moore, in press, Arcyana, in press). The mineralogy and the chemistry of the rock recovered in the FAMOUS area are relatively well known (Arcyana, in press) and could serve as a reference for the study of compositional variation between rift valley and transform fault volcanism. In order to compare the different rock types encountered in the rift valley and those from transform faults in the Atlantic ocean, the crystallization index (C.I. $=A n+2.57003$ Endi)$+($ Fo +0.700837 Enhy $)+\mathrm{Mg}$ Spinel; Poldervaart and Parker, 1964) is used. The crystallization index represents the converted normative minerals of "petrogeny's primitive system" and has the advantage of including both the felsic and the mafic constituents of basaltic rocks. A diagrammatic representation of the C.I. versus $\mathrm{SiO}_{2}, \mathrm{TiO}_{2}, \mathrm{Fe}_{2} \mathrm{O}_{3}+\mathrm{FeO}, \mathrm{Al}_{2} \mathrm{O}_{3}$ and $\mathrm{K}_{2} \mathrm{O}$ for the specimens taken from the Rift Valley near $36^{\circ}-37^{\circ} \mathrm{N}$ is shown on Figures 2,3 and 4. This diagram defines the field of the major basalt types encountered in the surveyed region (Fig. 2). The most mafic rocks are the picritic basalts with $\mathrm{Mg}$-enriched olivine and with C.I. higher than 64 . The picritic basalts are characterized by olivine megacrysts and phenocrysts up to $35-40 \%$; they have low $\mathrm{SiO}_{2}(<47 \%)$ and $\mathrm{TiO}_{2}(<0.7 \%)$ contents (Fig. 2$)$. The highly phyric plagioclase basalts (H.P.P.B.) are made up essentially of 30-35\% large Ca-rich plagioclase megacrysts and phenocrysts and have a C.I. value (65-70) similar to that of the picritic basalts (Fig. 2). However the H.P.P. basalts have higher $\mathrm{Al}_{2} \mathrm{O}_{3}$ $(>17 \%)$, and $\mathrm{SiO}_{2}(46-49 \%)$ contents and a lower $\mathrm{Fe}_{2} \mathrm{O}_{3}+\mathrm{FeO}(<8 \%)$ content than the picritic basalt (Figs. 2, 3). The moderately phyric plagioclase basalts (M.P.P.B.) have plagioclase phenocrysts and microphenocrysts. The M.P.P. basalts having an $\mathrm{Al}_{2} \mathrm{O}_{3}$ content of $16-17 \%$ and a $\mathrm{SiO}_{2}$ content of $49-50 \%$ are similar to the high-alumina tholeiites commonly found on mid-oceanic ridges (Aumento, 1968; Miyashiro et al., 1969) Figs. 2, 3).

The olivine basalts having a C.I. value comprised between 45 and 47 consist primarily of olivine phenocrysts and microphenocrysts. They have an $\mathrm{SiO}_{2}$

Fig. 2. C.I. and oxides $\left(\mathrm{TiO}_{2}, \mathrm{Fe}_{2} \mathrm{O}_{3}+\mathrm{FeO}, \mathrm{SiO}_{2}\right)$ variation diagram of volcanics from the M.A.R. near $36^{\circ} \mathrm{N}(\square)$ indicates the picritic basalts from the inner floor of the Rift Valley. $(\theta)$ are the highly phyric plagioclase basalts from the Rift Valley walls. $(0)$ are the moderately phyric plagioclase basalt from the walls and the inner floor. ( $\Delta$ ) are the olivine basalts from the inner floor. $(x)$ are the pyroxene basalts. The chemistry of these rocks are reported elsewhere (Bougault and Hekinian 1974). Samples 1,2,3 and 4 were taken by the submersible ARCHIMEDE on the rift valley inner floor (Arcyana, 1975). Samples 22, 23, 24, 41, 42 and 43 were dredged on the southern wall of Fracture Zone "A" by the R.V. Charcot in 1974. Samples 3-1 (CH 31-DR 3-1), 3-2 (CH 31-DR 3-2), 2-1 (CH 31-DR 2-1), 10-1 (CH 31-DR 10-1), 10-2 (CH 31-Dr 10-2) are from the eastern and western walls and sample 12-1 (CH 31-Dr 12-1) is from the inner floor of the Rift Valley 
Comparative Geochemistry of Volcanics from Rift Valleys


Fig. 2





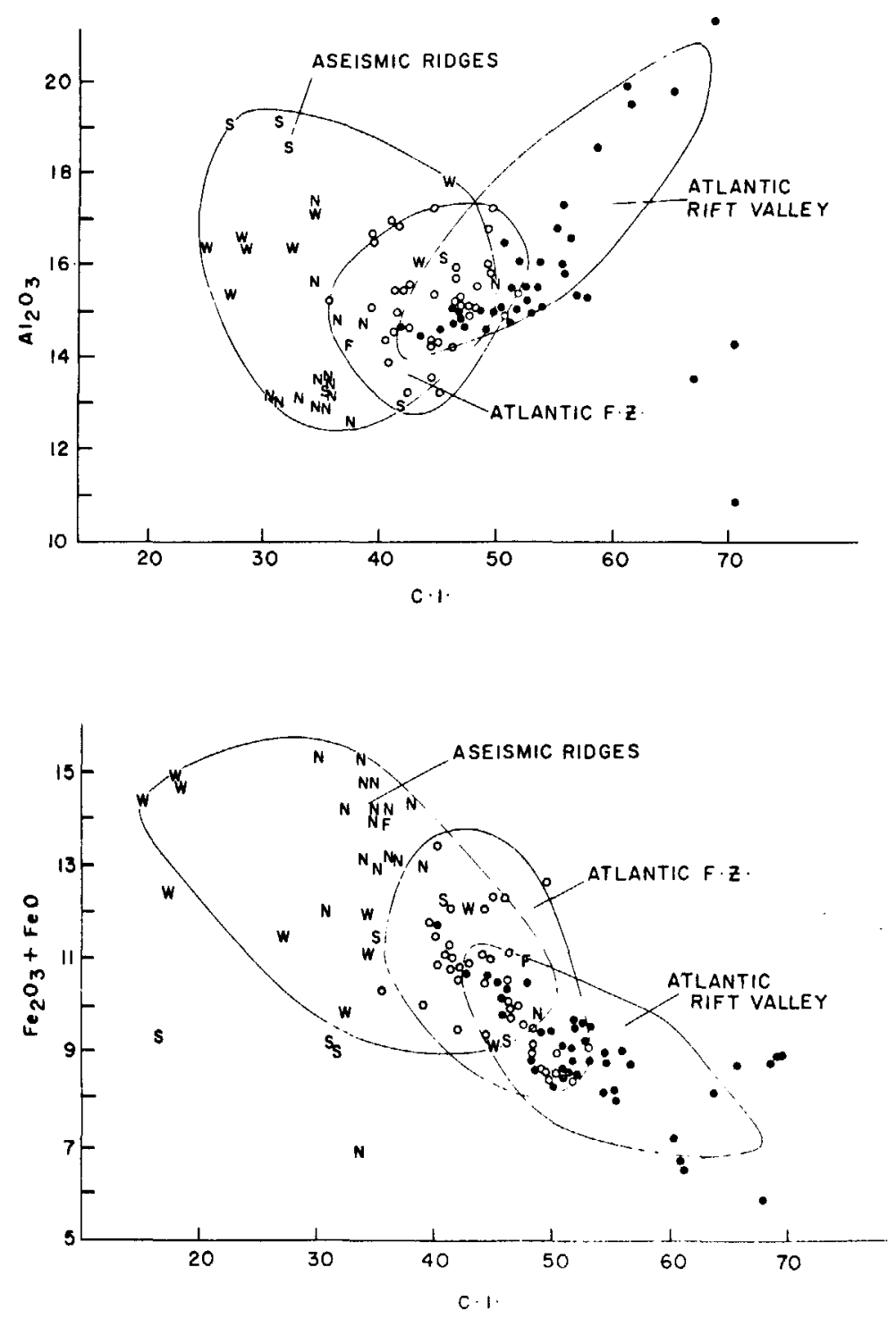

Fig. 3. C.I. versus $\mathrm{Fe}_{2} \mathrm{O}_{3}+\mathrm{FeO}$ and $\mathrm{Al}_{2} \mathrm{O}_{3}$. Variation diagram of M.A.R. Rift Valley, M.A.R. Transform faults and aseismic ridges. The solid dots indicate the distribution of M.A.R. Rift Valley samples from near $36^{\circ} 50^{\prime} \mathrm{N}$ reported in Figure 2. The empty circles are the distribution of basaltic rocks from M.A.R. transform faults. S, F. W and $N$ indicates the volcanics from the Cocos, the Iceland-Faeroes, the Walvis and the Ninetyeast Ridges respectively

Fig. 4. $\mathrm{K}_{2} \mathrm{O}-\mathrm{TiO}_{2}$ Variation diagram of basaltic and other differentiated rocks from various oceanic provinces. The top diagram represents the various types of basaltic rocks encountered near $36^{\circ} 50^{\prime} \mathrm{N}$ (Symbols are the same as in Figure 2). The middle diagram shows the field of M.A.R. Rift Valley rocks (black area) compared to transform faults and aseismic ridge rocks. S, F, W and $\mathrm{N}$ indicate the volcanics from the Cocos, the Iceland-Faeroes, the Walvis and the Ninetyeast Ridge respectively. The bottom diagram shows the volcanics from Iceland $(I)$ and those from the Azores $(C)$. The alkali-basalts data are from Esenwein (1929). Sigvaldason (1969) and Thorarinson et al. (1973). The andesitic rocks are from Carmichael (1964) and from Girod (1972). The tholeites are from Carmichael (1964) and from Sigvaldason (1969) 
Comparative Geochemistry of Volcanics from Rift Valleys
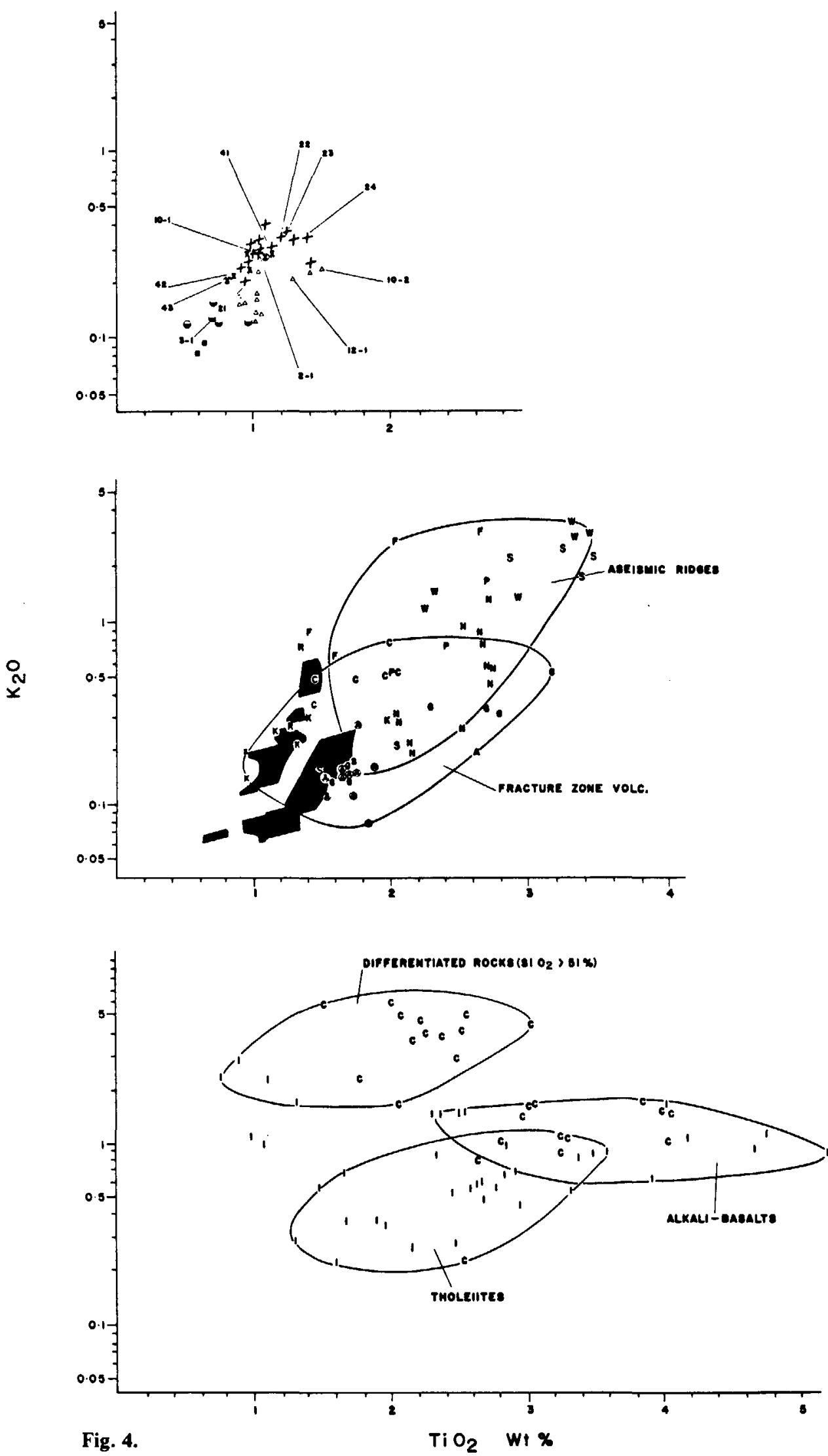
content $(49-51 \%)$ and $\mathrm{TiO}_{2}$ content $(0.8-1.3 \%)$ higher than both the H.P.P. basalt and the picritic basalt (Fig. 2). Another type of basalt encountered in the rift valley near $36^{\circ} 50^{\prime} \mathrm{N}$ is the plagioclase-pyroxene basalts. Details on the petrology of these rocks are published elsewhere (Arcyana, in press) which have the lowest values of C.I. (53) and are characterized by a higher $\mathrm{TiO}_{2}$ $(<1 \%)$, higher $\mathrm{Fe}_{2} \mathrm{O}_{3}+\mathrm{FeO}(<8.5 \%)$ and a lower $\mathrm{Al}_{2} \mathrm{O}_{3}(<15 \%)$ content than the other types of rocks (Figs. 2,3). Petrographic details on the above basalts are published elsewhere (Arcyana, in press).

The compositional variation within the samples from the FAMOUS area is similar to other Mid-Atlantic Rift Valley volcanics. Since the rock classification for the samples collected in the FAMOUS area was not used for previously described rocks it is difficult to assign similar names to other basaltic rocks found in different provinces, especially where there is a lack of detailed petrographic description. However normative analyses and C.I. values have been used in order to group the different basalt types found in the literature in the same way as adopted in this study. The diagrammatic representation of C.I. versus $\mathrm{Al}_{2} \mathrm{O}_{3}, \mathrm{Fe}_{2} \mathrm{O}_{3}+\mathrm{FeO}$ and of $\mathrm{TiO}_{2}$ versus $\mathrm{K}_{2} \mathrm{O}$ of volcanics from the M.A.R. rift valleys are shown in Figure 3 and 4 . The previously reported volcanics from the M.A.R. were collected from both the walls and adjacent fractured plateau and from the inner floor. Only a few dredge hauls were found to be from the inner floor of the rift valley near $28^{\circ} \mathrm{N}$ and $45^{\circ} \mathrm{N}$ (Nicholls, 1965; Muir et al., 1966; Aumento, 1968) of the North Atlantic ocean (Fig. 1). All of these dredges contain olivine basalts having normative olivine of 7-20 percent and a C.I. of 47-60 (Fig. 3). One picritic basalt with more than 30 percent normative olivine and a C.I. of 60 was also found in the inner floor near $45^{\circ} \mathrm{N}$ (Muir et al., 1964). Moderately phyric plagioclase basalts (M.P.P.B.) with an $\mathrm{Al}_{2} \mathrm{O}_{3}$ content of $16-17 \%$ and a C.I. of $50-60$ were also associated with the olivine basalts (Fig. 3). Highly phyric plagioclase basalts with an $\mathrm{Al}_{2} \mathrm{O}_{3}$ content of about 20 percent and a C.I. value higher than 60 were found on the rift valley walls near $45^{\circ} \mathrm{N}$ (Aumento, 1968) (Fig. 3). Other dredges (V 25DR 1 ; V 25-DR 4) taken near the Kane Fracture Zone are from the rift valley but the exact location is uncertain (Miyashiro et al., 1969; Shido et al., 1972). They consist mainly of olivine basalts with $7-11 \%$ normative olivine and C.I. between 46 and 51 (Fig. 3). High alumina basalts (corresponding to M.P.P. basalts) with an $\mathrm{Al}_{2} \mathrm{O}_{3}$ content of $16-17 \%$ and a C.I. of $46-50$ were also reported from the same dredge haul (Miyashiro et al., 1969; Shido et al., 1971) (Fig. 3). Basalts enriched in clinopyroxene from $45^{\circ} \mathrm{N}$ (Aumento, 1968) and from $36^{\circ} \mathrm{N}$ plot on a separate field having a narrow range $\mathrm{TiO}_{2}$ content $(1.15$ $1.7 \%)$ and a large range of $\mathrm{K}_{2} \mathrm{O}$ content $(0.2-0.7 \%)$ (Fig. 4). All the M.A.R. rift valley samples have a $\mathrm{TiO}_{2}$ and a $\mathrm{K}_{2} \mathrm{O}$ content lower than $1.8 \%$ and $0.7 \%$ respectively (Fig. 4 ).

Other elements showing a range of variability between different basaltic rocks from the M.A.R. rift valley are chromium and nickel (Fig. 5). These trace elements enter readily into the early formed crystalline phases and hence they are affected by the crystal accumulation of olivine and spinel. The rocks collected from the M.A.R. rift valley can be divided into four distinct groups: 1) the picritic basalts having a $\mathrm{Cr}$ and $\mathrm{Ni}$ content $>500 \mathrm{ppm}, 2$ ) the olivine 

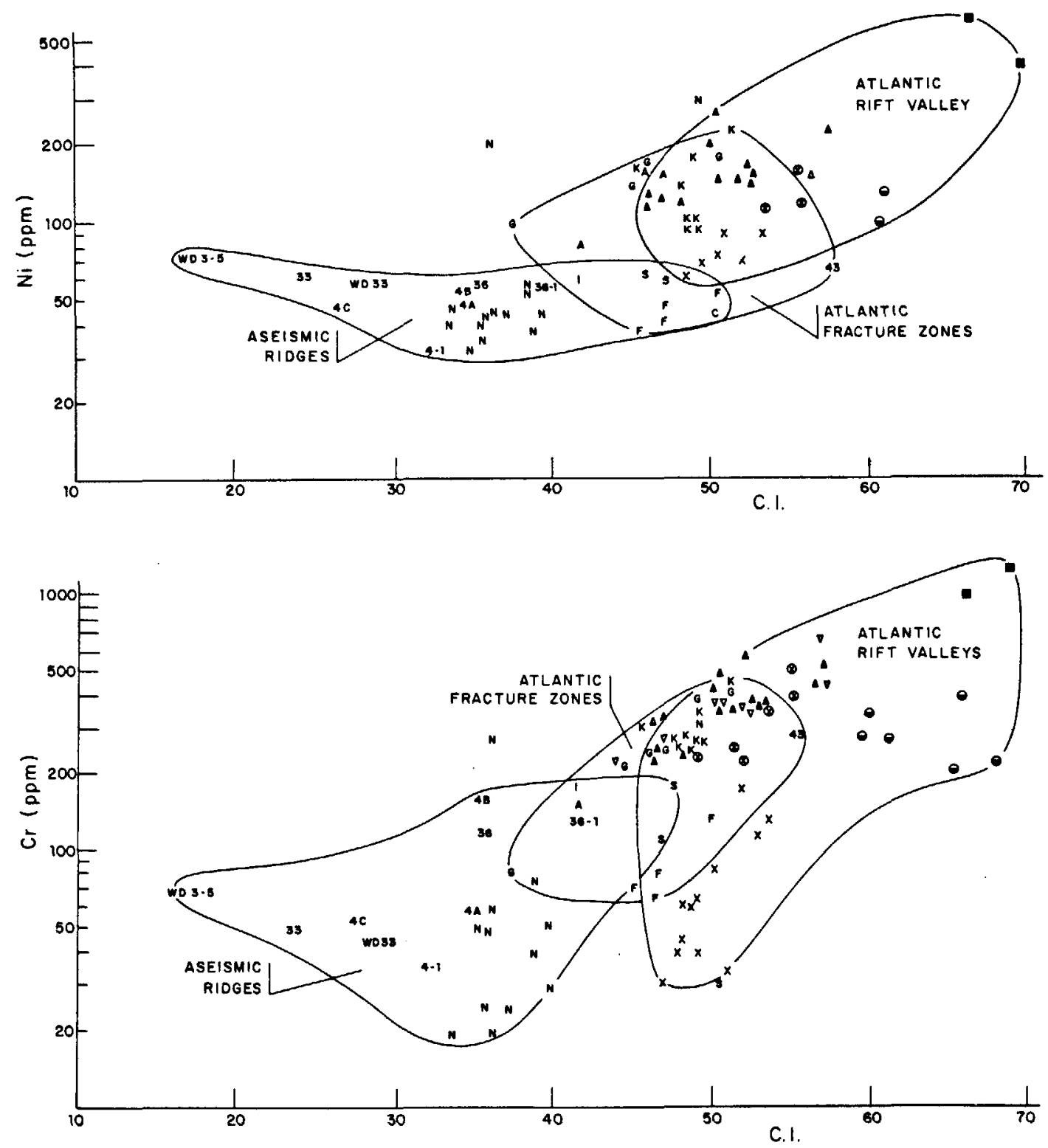

Fig. 5. $\mathrm{Cr}$ and $\mathrm{Ni}$ versus $\mathrm{C}$.I. variation diagram of volcanics from various tectonic settings. $K$ basaltic rocks form the Kane Fracture Zone (Thompson et al., 1971). $A$ basaltic rocks from the intersection of the Rift Valley with the Atlantis transform fault (Thompson et al., 1971). $G$ basalts from the Charlie-Gibbs transform fault, (Hekinian and Aumento, 1973), $\nabla$ basalts from the M.A.R. Rift Valley, (Muir et al., 1964; Aumento, 1968; Nicholls and Islam, 1971). X pyroxene basalts from the M.A.R. Rift Valley at $45^{\circ} \mathrm{N}$ (Aumento, 1968; Bougault and Hekinian, 1974). O moderately phyric plagioclase basalt (high alumina plagioclase basalts) from M.A.R. Rift Valley near $45^{\circ} \mathrm{N}$, (Aumento, 1968; Bougault and Hekinian, 1974). $(\theta)$ highly phyric plagioclase basalts from the M.A.R. Rift Valley near $45^{\circ} \mathrm{N}$, (Aumento, 1968; Bougault and Hekinian, 1974. $\triangle$ olivine basalts from the Rift Valley near $36^{\circ} 50^{\prime} \mathrm{N}$ (Bougault and Hekinian, 1974). picritic basalts from the Rift Valley near $36^{\circ} 50^{\prime} \mathrm{N}$ (Bougault and Hekinian, 1974). $N$ are pyroxene enriched rocks from the Ninetyeast Ridge (Thompson et al., 1974; Bougault, 1974). 4 B, 4C, 4A, 4-1, WD 3-5, WD 33 and 33 are basaltic rocks from the Walvis Ridge $(W) .36$ (16-158-36-c/c) and 36-1 (16-158-36-1-146$150 \mathrm{~cm}$ ) are from JOIDES holes in the Cocos Ridge. $s$ indicates also published data (Engel and Chase, 1965) of volcanics from the Cocos Ridge. I indicates samples from the DSDP drilled holes from the Camegie Ridge (16-157) 
and moderately phyric plagioclase basalts with a $\mathrm{Cr}$ and $\mathrm{Ni}$ content comprised between 100 and $400 \mathrm{ppm}, 3$ ) the plagioclase pyroxene basalts having a $\mathrm{Cr}$ and $\mathrm{Ni}$ content of $20-100 \mathrm{ppm}$ (Fig. 5) and the H.P.P. basalts having similar $\mathrm{Cr}$ and $\mathrm{Ni}$ content $(100-600 \mathrm{ppm})$ but a higher C.I. value $(5565)$ than do the olivine basalts (Fig. 5).

\section{Volcanics from M.A.R. Transform Faults}

The rocks from the Charlie Gibbs fracture near $53^{\circ} \mathrm{N}$ (Hékinian and Aumento, 1968: Campsie et al., 1973). from the Oceanographer fracture near $36^{\circ} \mathrm{N}$ (Shibata and Fox, 1974). from the Atlantis fracture near $30^{\circ} \mathrm{N}$ (Muir et al., 1966; Miyashiro et al., 1969; Shido et al., 1969) and from the Kane fracture near $23^{\circ} \mathrm{N}$ (Miyashiro et al.. 1969: Shido et al., 1971: Kay et al., 1971) have high $\mathrm{TiO}_{2}(1.5-2.5 \%)$, and $\mathrm{Fe}_{2} \mathrm{O}_{3}+\mathrm{FeO}(10.13 \%)$ contents and a low content of $\mathrm{Al}_{2} \mathrm{O}_{3}(<18 \%)$ and low C.I. values $\left.(40)-47\right)$ characteristic of the plagioclasepyroxene basalt type of rock found near $36^{\circ} 37^{\circ} \mathrm{N}$ (Figs. 2, 3, 4). Another type of basalt encountered in these fracture zones is the moderately phyric plagioclase basalts, also called high alumina tholeiites because of their relatively high $\mathrm{Al}_{2} \mathrm{O}_{3}$ content $(15-18 \%)$. These rocks are characterized by C.I. values of about $48-52$, their $\mathrm{TiO}_{2}$ content of $1.0-1.6 \% . \mathrm{Fe}_{2} \mathrm{O}_{3}+\mathrm{FeO}$ content less than $10 \%$, and $\mathrm{SiO}_{2}$ content of $49-51 \%$ (Figs. 3, 4). Two alkali-basalts having normative olivine of 8-14 percent were found in the St. Paul's fracture (Melson and Thompson, 1973) and in the Romanche fracture (Bonatti et al. 1971). However one moderately phyric plagioclase basalt $\left(\mathrm{C} . \mathrm{I} .=53: \mathrm{Al}_{2} \mathrm{O}_{3} \simeq 16^{\circ} \mathrm{o}\right.$ and two basalts having a low C.I. $(<40)$, and high content of $\mathrm{TiO}_{2}(22.5 \%)$ and $\mathrm{SiO}_{2}(50-52 \%)$, similar to the plagioclase-pyroxene basalts described here. were also collected in the Romanche fracture (Bonatti et al.. 1971) and in the St. Paul's fracture (Meslon and Thompson, 1973). The Mid-Atlantic Ridge transform fault volcanics have a higher $\mathrm{TiO}_{2}$ content $(1.5-3 \%)$ and a wider range of $\mathrm{K}_{2} \mathrm{O}$ content $(0.10-1 \%$ ) than the M.A.R. rift valley rocks (Fig. 4).

The volcanics from the transform faults show decreasing of the $\mathrm{Cr}$ and $\mathrm{Ni}$ content with decreasing values of C.I. (Fig. 5). However most samples plot in the field of the lower C.I. and $\mathrm{Cr}$ values with that of the olivine basalt and the plagioclase-pyroxene basalts (Fig. 5). The transform fault basalts fall within an intermediate field of $\mathrm{Cr}$ and $\mathrm{Ni}$ content $(100-500 \mathrm{ppm}$ and $20-200 \mathrm{ppm}$ respectively) between basalts of the Rift valley and those from aseismic Ridges (Fig. 5, Table 1).

\section{Volcanics from Aseismic Ridges}

Very little is known about the basement composition of aseismic ridges. Only scattered data on the petrology of drilled holes and dredged material from four aseismic ridges are found in the literature: the Cocos and the Carnegie ridges (Pacific ocean) (Campsie et al., 1972: Engel and Chase, 1965; Dalrymple and Cox, 1968), the Iceland-Faeroe Ridge (North Atlantic ocean) (Noe-Nygaard, 1962), the Walvis Ridge (South Atlantic ocean) Hékinian, 1972) and 
the Ninetyeast Ridge (Indian ocean) (Hékinian, 1973; Kempe, 1974; Thompson et al., 1974). A common characteristic for aseismic ridge basaltic rocks is that they all have low C.I. $(<50)$ values with respect to the M.A.R. transform fault and Rift Valley volcanics (Fig. 3). Their low C.I. values (10-50) are primarily due to the more sodic plagioclase content $\left(<A n_{70}\right)$ (Hékinian, 1974; Campsie et al., 1973; Kempe, 1974), the lower magnesian olivine content, and the higher iron oxide mineral content (Hékinian, 1973; Hékinian, 1974) of the basaltic rocks. The picritic basalt found on the Ninetyeast Ridge (DSDP site 253; Kempe, 1974) the most mafic type of rock encountered on aseismic ridges and differs from the picritic basalt found in the Rift valley near $45^{\circ} \mathrm{N}$ and $36^{\circ} 50^{\prime} \mathrm{N}$ (C.I. $>60$ ) by its low C.I. value (49) (Figs. 2, 3). Pyroxene basalts with modal pyroxene and a normative pyroxene content of $20-50 \%$ and olivine basalts with normative olivine up to $16 \%$ were also found on the Ninetyeast Ridge (Hékinian, 1973; Kempe, 1974). The Faeroe-Iceland basalts are also enriched in modal and normative pyroxene $(20-40 \%)$ and in iron oxide minerals $(10-15 \%)$ (Noe-Nygaard, 1962). The Cocos and Walvis Ridges both have volcanics with alkaline affinities and enriched in normative olivine $(10-12 \%)$ content (Engel and Chase, 1965; Hékinian, 1974) (Table 1). Other volcanics from the Cocos Ridge have quartz in their norm and a normative pyroxene of $27-30 \%$ (Campsie et al., 1973). The low pyroxene content in some of the Cocos Island samples (Dalrymple and Cox, 1968) is due to the preferential crystallization of the plagioclase. The volcanics which are the most enriched in $\mathrm{Al}_{2} \mathrm{O}_{3}(16-23 \%)$ within the aseismic ridge rocks are those found on the Cocos (Engel and Chase, 1965; Dalrymple and Cox, 1968) and those from the Walvis Ridge (Hékinian, 1974). These rocks containing large plagioclase phenocrysts could be compared to the H.P.P. basalts found near $45^{\circ} \mathrm{N}$ and $36^{\circ} 50^{\prime} \mathrm{N}$. The transform fault volcanics have the lowest range of $\mathrm{Al}_{2} \mathrm{O}_{3}$ content $(12-17 \%)$ when compared to both aseismic ridges and Rift Valley rocks (Fig. 3). The range of the total iron content of the aseismic ridge volcanics $\left(\mathrm{Fe}_{2} \mathrm{O}_{3}+\mathrm{FeO}=8-15 \%\right)$ is higher than both M.A.R. rift valley $\left(\mathrm{Fe}_{2} \mathrm{O}_{3}+\mathrm{FeO}=5-11 \%\right)$ and M.A.R. transform fault $\left(\mathrm{Fe}_{2} \mathrm{O}_{3}+\mathrm{FeO}=7-13 \%\right)$ rocks (Fig. 3). All the volcanics from aseismic ridges have a wider and higher range of $\mathrm{TiO}_{2}(1.7-4 \%)$ and $\mathrm{K}_{2} \mathrm{O}(0.2-4 \%)$ contents than do both transform fault and Rift valley volcanics (Fig. 4). The transform fault rocks have overlapping and intermediate contents of $\mathrm{TiO}_{2}$ and $\mathrm{K}_{2} \mathrm{O}$ between the M.A.R. Rift valley and aseismic ridge volcanics (Fig. 4). The alkali-basalts, the tholeiites, and the differentiated rocks from elevated volcanic edifices, such as Iceland (Carmichael, 1964; Sigvaldason, 1969) and the Azores (Esenwein, 1929; Girod, 1972) differ in their $\mathrm{TiO}_{2}(1.5-5 \%)$ and $\mathrm{K}_{2} \mathrm{O}(0.3-5 \%)$ contents from both the transform fault and Rift Valley rocks but are similar to the aseismic ridge volcanics (Fig. 4).

The available data on the $\mathrm{Cr}$ and $\mathrm{Ni}$ content of aseismic ridges show that they have lower values of these elements $(<200 \mathrm{ppm})$ than do Rift valley and transform fault rocks (Fig. 5, Table 1). The volcanics having the highest $\mathrm{Cr}$ content (90-300 ppm) are the picritic basalt (Kempe, 1974) from the Ninetyeast Ridge and H.P.P. basalt from the Cocos Ridge (Fig. 5). The lowest $\mathrm{Cr}(10$ $90 \mathrm{ppm}$ ) content is found in the pyroxene-enriched basalts from the aseismic ridges. 
Table 1. Trace element analyses of volcanics from aseismic ridges and from the north-facing wall of transform fault "A" near $37^{\circ} \mathrm{N}$ in the Atlantic. The analyses were done by photoelectric emission spectrometer (W.H.O.I.)

\begin{tabular}{|c|c|c|c|c|c|c|c|c|c|c|c|c|c|c|c|c|c|c|}
\hline \multirow[b]{2}{*}{ Lab $N^{\circ}$} & \multicolumn{4}{|c|}{ Carnegie Ridge } & \multicolumn{2}{|c|}{ Cocos ridge } & \multicolumn{7}{|c|}{ Walvis Ridge } & \multicolumn{5}{|c|}{ Transform fault "A" } \\
\hline & & & & & 36 & $36-1$ & $\begin{array}{l}\text { WD } \\
33\end{array}$ & $\begin{array}{l}\text { WD } \\
3-5\end{array}$ & 33 & $4-1$ & $4 \mathrm{~A}$ & $4 B$ & $4 \mathrm{C}$ & 22 & 23 & 24 & 41 & 43 \\
\hline Field $\mathrm{N}^{\circ}$ & $\frac{\frac{\pi}{d}}{\dot{d}}$ & 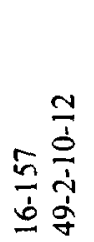 & 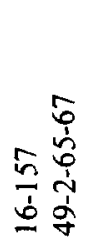 & 동 $\frac{\infty}{\dot{m}}$ & 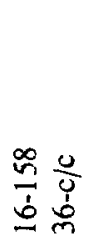 & 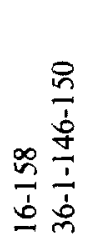 & $\begin{array}{l}a \\
\alpha \\
\infty \\
\infty \\
\dot{n} \\
\dot{y} \hat{3}\end{array}$ & 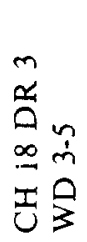 & $\begin{array}{l}m \\
m \\
m \\
\alpha \\
a \\
a \\
\infty \\
\square \\
\vec{U}\end{array}$ & 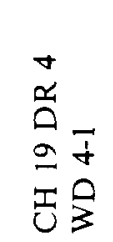 & $\begin{array}{l}\varangle \\
j \\
\alpha \\
a \\
a \\
a \\
u\end{array}$ & $\begin{array}{l}a \\
\dot{y} \\
a \\
a \\
a \\
a \\
J\end{array}$ & $\begin{array}{l}u \\
\dot{y} \\
\dot{x} \\
0 \\
a \\
a \\
\vdots \\
u\end{array}$ & 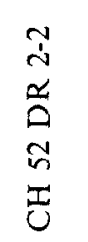 & $\begin{array}{l}\hat{\sim} \\
\alpha \\
0 \\
\tilde{a} \\
\tilde{n} \\
\tilde{U}\end{array}$ & 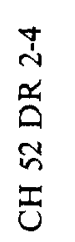 & 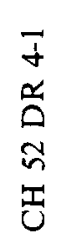 & 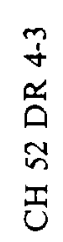 \\
\hline B & $<5$ & $<5$ & $<5$ & $<5$ & $<5$ & $<5$ & 15 & 16 & 16 & 32 & 29 & 23 & 50 & 7 & 6 & 6 & 7 & 3 \\
\hline $\mathrm{Li}$ & 9 & 7 & 10 & 7 & 4 & 5 & 18 & 26 & 16 & 80 & 16 & 17 & 18 & 3 & 3 & 4 & 3 & 3 \\
\hline $\mathrm{V}$ & 385 & 370 & 365 & 330 & 350 & 365 & 550 & 335 & 540 & 445 & 365 & 360 & 465 & 260 & 245 & 270 & 250 & 235 \\
\hline $\mathrm{Cr}$ & 175 & 215 & 240 & 160 & 115 & 130 & 47 & 70 & 49 & 38 & 63 & 190 & 55 & 80 & 68 & 72 & 135 & 290 \\
\hline Co & 60 & 57 & 54 & 54 & 56 & 53 & 96 & 49 & 62 & 65 & 67 & 39 & 60 & 43 & 38 & 41 & 35 & 41 \\
\hline $\mathrm{Ni}$ & 60 & 60 & 57 & 52 & 55 & 59 & 60 & 74 & 64 & 31 & 57 & 51 & 48 & 47 & 42 & 45 & 53 & 66 \\
\hline $\mathrm{Cu}$ & 165 & 145 & 140 & 145 & 130 & 135 & 140 & 110 & 205 & 40 & 120 & 20 & 135 & 60 & 58 & 59 & 50 & 63 \\
\hline $\mathrm{Sr}$ & 160 & 170 & 150 & 180 & 170 & 180 & 290 & 400 & 385 & $>400$ & 330 & 380 & $>400$ & 91 & 86 & 96 & 86 & 100 \\
\hline $\mathrm{Ba}$ & 34 & 36 & 30 & 41 & 40 & 51 & 330 & 320 & 440 & 535 & 245 & 280 & 535 & 52 & 42 & 53 & 36 & 43 \\
\hline$Y$ & 39 & 43 & 38 & 42 & 37 & 35 & 48 & 51 & 42 & 51 & 40 & 32 & 60 & 26 & 21 & 23 & 23 & 20 \\
\hline $\mathrm{Zr}_{\mathbf{r}}$ & 165 & 165 & 145 & 165 & 135 & 120 & 190 & 185 & 205 & 225 & 180 & 175 & 230 & 65 & 55 & 58 & 51 & 43 \\
\hline
\end{tabular}




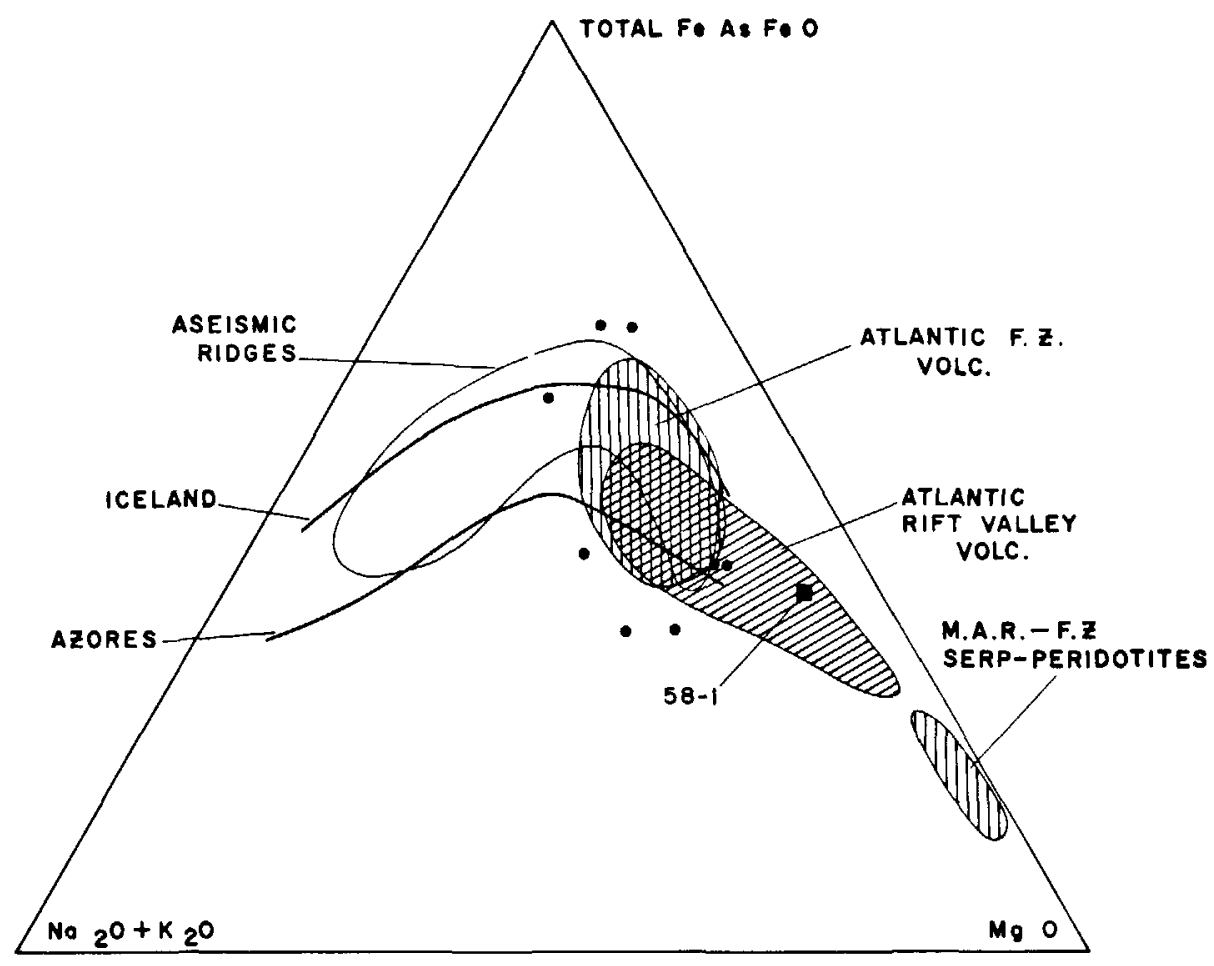

Fig. 6. AFM variation diagram of volcanics from the M.A.R. Rift Valley compared to other oceanic provinces. $(/ / / /)$ indicates the field of M.A.R. Rift Valley (walls and inner floor) samples (from present study; Muir et al., 1966; Aumento, 1968; Melson and Thompson, 1971; Hekinian and Aumento, 1973). (1111) indicates field of transform fault rocks (from present study; Muir et al., 1966; Miyashiro et al., 1969; Bonatti et al, 1971; Kay et al., 1971; Shido et al., 1971; Shibata and Fox, 1974). ( $\bullet$ ) indicates babbroic rocks associated with the Kane (Miyashiro et al., 1969) and with the Romanche transform fault (Bonatti et al., 1971). Aseismic Ridge Volcanics consist of basalt and differentiated rocks (Noe-Nygaard, 1962; Engel and Chase, 1965; Dalrymple and Cox, 1968; Hekinian, 1972; Hekinian, 1974). ( 1 ) indicates a picritic basalt from the Ninetyeast Ridge (Kempe, 1974). The tholeiitic basalts, the alkali basalts and the differentiated rocks from Iceland and the Azores were reported from the data of Esenwein (1924), Carmichael (1964), Sigvaldason (1969). Girod (1974) and Thorarinson et al. (1973)

The continuity in their chemical parameters for the various volcanic provinces could indicate a common origin from a primitive Rift Valley type basalt magma which, upon a single process of differentiation, may have given rise to the various basalt types observed. The AFM ternary diagram expresses more adequately this type of differentiation due mostly to the crystal-liquid fractionation (Fig. 6). However the transform fault volcanics from the M.A.R. including those from near $36^{\circ} 50^{\prime} \mathrm{N}$ are characterized by a higher $\mathrm{FeO} / \mathrm{mgO}$ ratio than those from the Rift Valley (Fig. 6). The same diagram also shows the tholeiite alkali basalt differentiated rock series from Iceland (Carmichael, 1924; Sigvaldason, 1969; Thorarinson et al., 1973) and the Alkali-trachyte series from the azores (Esenwein, 1939; Girod, 1972). Both these series show their most mafic end members having a $\mathrm{FeO} / \mathrm{MgO}$ ratio similar to that of transform fault basalts (Fig. 6). The origin of ultramafic intrusives in fracture zones is still uncertain and may be unrelated to the basaltic rocks found in close proximity in M.A.R. 


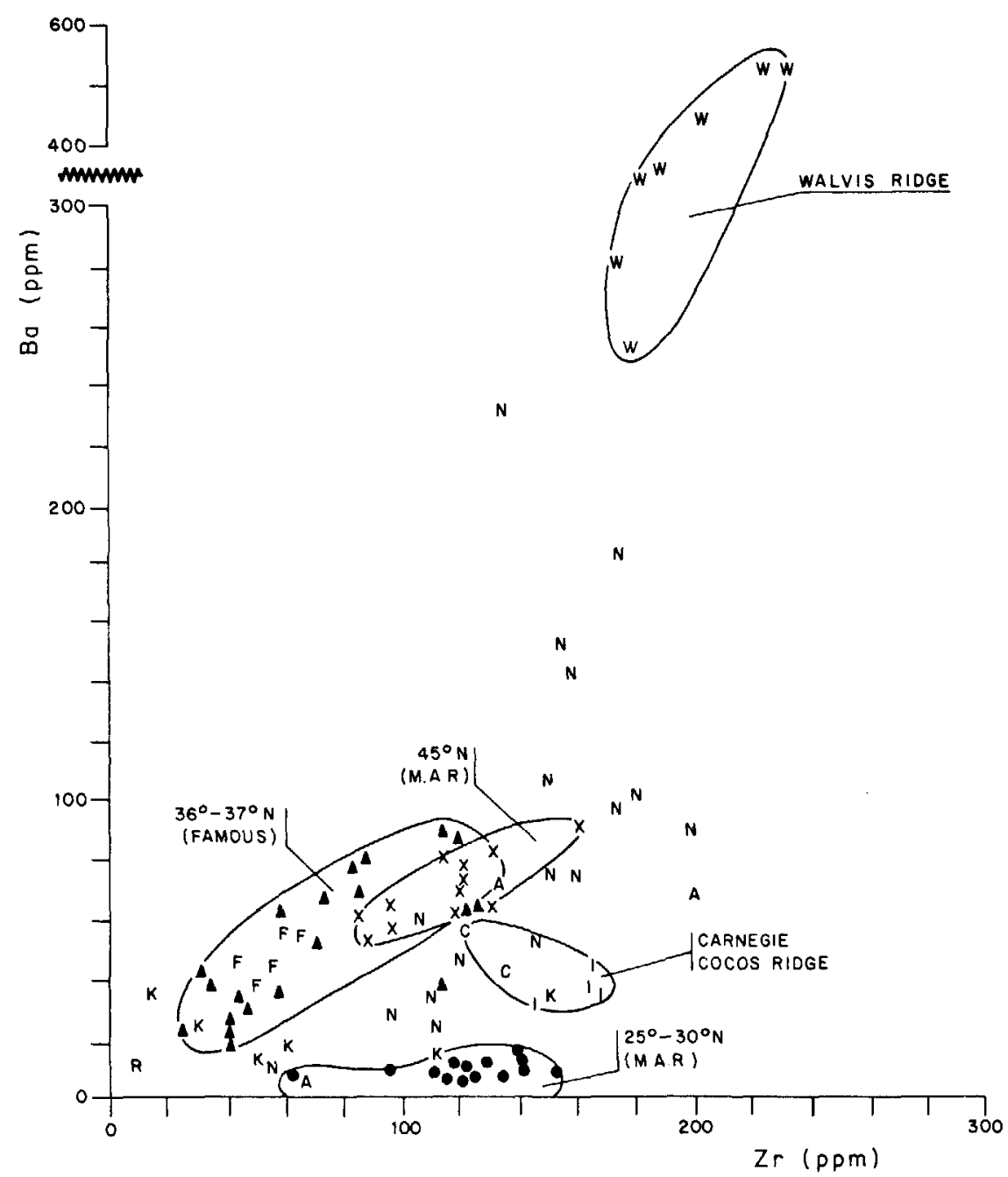

Fig. 7. Ba-Zr variation diagram of Mid-Atlantic Ridge Rift Valley rocks from $45^{\circ} \mathrm{N}$ (X) (Aumento, 1963); from $36-37^{\circ} \mathrm{N}(\Delta)$ from $30^{\circ} \mathrm{N}$ and $25^{\circ} \mathrm{N}(\bullet)$ Thompson et al., 1972, 1973). The volcanics from fracture zone "A" near $37^{\circ} \mathrm{N}(\mathrm{F})$ is also shown. Other Mid-Atlantic fracture zones data includes the Kane $(K)$, the Atlantis $(A)$, and the Romanche $(R)$ (Thompson et al., 1972, 1973). The aseismic ridge volcanics are represented by those from the Walvis $(W)$, the Ninetyeast $(N)$, the Cocos $(s)$ and the Carnegie $(I)$ (station 16-157)

transform faults (Bonatti et al., 1971). The exposed ultramafics from the M.A.R. transform faults show the lowest $\mathrm{FeO} / \mathrm{MgO}$ ratio $(0.15-0.25)$ when compared to other oceanic rocks (Fig. 6). As suggested for the olivine concentration in the picritic basalts, the presence of peridotitic bodies in transform faults could also be due to the crystal accumulations of olivine derived from an olivine basalt melt. The occurrence of olivine gabbro in M.A.R. transform faults (Miyashiro et al., 1970; Bonatti et al., 1971) with $\mathrm{FeO} / \mathrm{MgO}$ ratios of $0.3-11$ similar to the picricit and the olivine basalts from the Rift valley near $36^{\circ} 50^{\prime} \mathrm{N}$, suggests that these olivine rich rocks could be the residual melt left after the fractionation of olivine. Zones of segregation (about $3 \mathrm{~cm}$ in diameter) of plagioclase and olivine having compositions similar to that of the olivine gabbros 
collected from a M.A.R. transform fault (Miyashiro et al., 1970) were found within a picritic basalt from the Rift Valley near $36^{\circ} 50^{\prime} \mathrm{N}$ (Arcyana, in press). While the $\mathrm{FeO} / \mathrm{MgO}$ ratio increases continuously from rift valley basalts to aseismic ridge rocks, other chemical parameters such as $\mathrm{Ba}$ and $\mathrm{Zr}$ seem to indicate a different grouping of the volcanics into distinct individual fields (Fig. 7). All the specimens from the Walvis Ridge are considerably higher in $\mathrm{Ba}$ ( $>240 \mathrm{ppm}$ ) than any of the other oceanic provinces (Fig. 7, Table 1). Even within the M.A.R. rift valley basalts there is a distinct difference in $\mathrm{Ba}$ and $\mathrm{Zr}$ content between the samples collected from near $36^{\circ}-37^{\circ} \mathrm{N}$ and $45^{\circ} \mathrm{N}$ $(\mathrm{Ba}-20-100 \mathrm{ppm})$ and those from $25^{\circ}-30^{\circ} \mathrm{N}(\mathrm{Ba}<20 \mathrm{ppm})$ (Fig. 7). Difference in large ion lithophile (LIL) element contents for these regions have been discussed elsewhere (White et al., 1975). The scattered data on fracture zones seem to point to a variable range of $\mathrm{Ba}-\mathrm{Zr}$ contents (Fig. 7). $\mathrm{Ba}$ and $\mathrm{Zr}$ do not enter into the basalt crystalline phases and hence are not influenced by differentiation process due to crystal accumulation. Hence it is probable that the various geological provinces have tapped magma originating from distinct and different source regions.

\section{Summary and Conclusions}

In summary it is found that the volcanics from near $36^{\circ} 50^{\prime} \mathrm{N}$ show a continuous C.I. variation trend going from the most mafic, such as the picritic basalts and the H.P.P. basalts to the least mafic end members such as the plagioclasepyroxene basalts. The olivine basalts and the M.P.P. basalts have intermediate values of C.I. $(45-56)$ between the picritic $(C . I .=67-70)$ and the plagioclasepyroxene basalt (C.I. 40-50). A survey of published data on basaltic rocks from the Mid-Atlantic Ridge show that the basaltic rocks from the M.A.R. Rift Valleys have a more mafic composition than those found in M.A.R. transform faults. The M.A.R. transform fault volcanics show higher $\mathrm{TiO}_{2}$ contents $(1-4 \%)$, higher $\mathrm{Fe}_{2} \mathrm{O}_{3}+\mathrm{FeO}$ contents $(8-14 \%)$ and lower C.I. values $(35-50)$ than do M.A.R. Rift valley rocks $(<2 \% ;<12 \%$ and $>40$ respectively). The transform fault volcanics have intermediate values of C.I. and $\mathrm{Cr}$ content $(50$ $500 \mathrm{ppm})$ and generally a higher range of $\mathrm{Ni}$ content $(50-300 \mathrm{ppm})$ than aseismic ridges. The basaltic rocks from aseismic ridges such as the Ninetyeast (Indian ocean) the Walvis (Atlantic ocean) the Iceland-Faeroe (Atlantic ocean) and the Cocos (Pacific ocean) ridges show a trend of fractionation beginning with rocks having an $\mathrm{FeO} / \mathrm{MgO}$ ratio similar to those of the M.A.R. transform faults but progressing farther towards iron and alkali enrichment than encountered in M.A.R. transform faults and Rift valley volcanics.

In addition to basaltic rocks, it is known that transform faults also have exposed intrusives of gabbroic and peridotitic composition which are similar to some crystal accumulates of olivine-plagioclase and olivine-spinel associations found in the picritic basalts of the Rift valley. It is possible that these gabbroic and peridotitic rocks represent minor intrusives derived by various degrees of fractionation from a basaltic melt. However, basalts from M.A.R. transform faults differ mainly from those from the M.A.R. Rift valley volcanics because 
they contain more felsic types of basaltic rocks. Thus transform faults have tapped different magma sources or faulting has exposed more fractionated type of basalts than those found in the M.A.R. Rift valley. The second hypothesis is more plausible since the plagioclase-pyroxene basalts of intrusive nature found in transform fault "A" of the FAMOUS area have a similar composition to those encountered in the Rift valley's wall at the same location (Arcyana, in press). Aseismic ridges have exposed more felsic types of volcanics than both transform faults and Rift valley rocks and appear to have undergone a greater degree of fractional crystallization.

The observed continuous chemical variation of the critical parameters (C.I., $\mathrm{Fe}_{2} \mathrm{O}_{3}+\mathrm{FeO}, \mathrm{TiO}_{2}, \mathrm{Al}_{2} \mathrm{O}_{3}, \mathrm{Cr}, \mathrm{Ni}$ ) used here suggests that the observed differences encountered in the volcanics from M.A.R. Rift valleys, the M.A.R. transform faults and the aseismic ridges is mainly due to a process of fractional crystallization. This does not necessarily imply that all the volcanics have a common parental magmatic origin. It is not excluded that within each structurally different province there is a distinct parent magma which could give rise to a continuous spectrum of crystal liquid variation through a process of fractional crystallization. This is suggested by the $\mathrm{Ba}$ and $\mathrm{Zr}$ distribution which groups the various volcanics into different structural provinces. The Walvis ridge rocks are the most enriched in $\mathrm{Ba}(>240 \mathrm{ppm})$. The Ninetyeast and the Cocos-Carnegie Ridge volcanics are also distinguishable by their Ba- $\mathrm{Zr}$ variation (Fig. 7). The M.A.R. rift valley rocks from $36^{\circ} 37^{\circ} \mathrm{N}$ and from $45^{\circ} \mathrm{N}$ are more enriched in $\mathrm{Ba}$ content $(20-100 \mathrm{ppm})$ than those from $25^{\circ}-30^{\circ} \mathrm{N}(<20 \mathrm{ppm})$.

Acknowledgements. Particular acknowledgement is given to the captain and crew of R.V. Jean Charcot for the 1974 cruise in the M.A.R. near $37^{\circ} \mathrm{N}$. Dr. V. Renard provided the dredge samples used here from Transform Fault "A". Some of the submersible samples were collected by Archimède (French Navy) during the 1973 FAMOUS (French American Mid-Ocean Undersea Survey) operation.

One of us (GT) supported by NSF Grant 22971 with the Woods Hole Oceanographic Institution (U.S.A.). V. Chapron, R. Thirion and N. Guillo helped to improve the manuscript.

\section{References}

Andel, Tj. H. van, Bowin. C.O.: Mid-Atlantic Ridge between $22^{\circ}$ and $23^{\circ}$ North latitude and the tectomics of Mid-ocean rises. J. Geophys. Res. 73, 1279-1298 (1968)

Arcyana: Transform fault and Rift Valley. Geology by bathyscaphe and diving saucer. Science 190 (4210), 108-116 (1975)

Arcyana: Petrological diversity and structural setting of basaltic rocks collected by manned submersibles from the Rift Valley of the Mid-Atlantic Ridge near $36^{\circ} 50^{\prime} \mathrm{N}$. Deep-Sea Res. (in press)

Aumento, F.: The Mid-Atlantic Ridge near $45^{\circ} \mathrm{N}$. II. Basalts from the area of Confederation Peak. Can. J. Earth Sci. 5, 1-21 (1968)

Bellaiche, G., Cheminée, J.L., Francheteau, J., Hékinian, R., Le Pichon, X., Needham, H.D., Ballard, R.D.: Rift Valley's Inner floor; first submersible study. Nature 250, 558-560 (1974)

Bonatti, E., Honnorez, J., Ferrara, G.: Peridotite-gabbrobasalt complex from the equatorial MidAtlantic Ridge. Phil. Trans. Roy. Soc. Lond., A 268, 385-402 (1971)

Bougault, $H_{\text {. }}$ : Distribution of first series transition metals in rocks recovered during DSDP leg 22 in the northeastern Indian Ocean. In: Initial Report DSDP 22, 449-457 (1974)

Bougault, H., Hékinian, R.: Rift valley in the Atlantic Ocean near $36^{\circ} 50^{\prime} \mathrm{N}$. Petrology and Geochemistry of basaltic rocks. Earth Planet. Sci. Letters 2A, 249-261 (1974) 
Comparative Geochemistry of Volcanics from Rift Valleys

Campsie, J., Bailey, J.C., Rasmunssen, M., Dittmer, F. : Chemistry of tholeiites from the Reykjanes ridge and Charlie Gibbs fracture zone. Nature 244. 71 (1973)

Carmichael. I.S.E.: The petrology of Thingmuli, a tertiary volcano in Eastern Iceland. J. Petrol. 5, (3), 435460 (1964)

Dalrymple, B.G., Cox. A.: Paleomagnetism, Potassium-Argon ages and petrology of some volcanic rocks. Nature 217, 323-326 (1968)

Engel, C.G., Chase, T.E.: Composition of basalts from seamounts off the west coast of Central America. US. Geol. Survey Profess. Papers 525-C. C161 C163 (1965)

Esenwein, P.: Zur Petrographie der Azonen. Z. Vulkanologie 12. 108223 (1929)

Francheteau. J., Le Pichon, X.: Marginal fracture zones as structural framework of continental margins in South Atlantic ocean. Am. Assoc. Petrol. (ieologists Buil. 56 (6), 991 ..1007 (1972)

Girod. M.: A propos des Andesites des Açores. (ontrib. Mineral. Petrol. 35, 159167 (1972)

Hekinian, R.: Volcanics from the Walvis Ridge in the south east Atlantic ocean. Nature 239. 91 (1972)

Hekinian, R.: Petrology of the Ninetyeast Ridge (Indian Ocean) compared to other aseismic ridges. Contrib. Mineral. Petrol. 43. 125147 (1974)

Hekinian, R., Aumento, F.: Rocks from the (iibbs Fracture zone and the Minia Seamount near $53^{\circ} \mathrm{N}$ in the Atlantic ocean. Marine Geol. 14. 47 72 (1973)

Kay, R. Hubbard. N.J., Gast. P.: Chemical charilcteristics and origin of oceanic ridge volcanic rocks. J. Geophys. Res. 75 (8), 15811613 (1970)

Kempe, D.R.C.: The petrology of the basalts, leg $26 \mathrm{in}$ inıtial report of D.S.D.P. U.S. Government Printung Office 26. 465-503 (1974)

McKenzie, D.A., Sclater, J.G. : The evolution of the Indian Ocean since the late cretaceous. Geophys. J. 25, 437-528 (1971)

Melson. W.G.. Thompson, G. : Petrology of a transform fault zone and adjacent ridge segment. Phil. Trans. Roy. Soc. London, 268, 423441 (1971)

Melson. W.G.. Thompson. G.: Glassy abyssal basalts, Atlantic sea-floor near St-Paul's rocks: Petrography and composition of secondary ciay minerals. (veol Soc. Am. Bull. 84. 703716 (1973)

Miyashiro, A., Shido, F.. Ewing. M.: Crystallıatıon and differentiatıon in abyssal tholerites and gabbros from mid-oceanc ridges. Earth Planet. Sci. Letters 7, 261265 (1970)

Miyashiro, A.. Shido, F., Ewing. M.: Diversity and origin of abyssal tholeitie from the Mid-Atlantic ridge near $24^{\circ}$ and $30^{\circ} \mathrm{N}$ latitude. Contrib. Mineral. Petrol. 23, 38.52 (1969)

Muir, I.D., Tilley, C.F., Scoon, J.H.: Basalts from the northern part of the Ritt zone of the Mid-Atlantic ridge, J. Petrol. 5, (3), 409. 434 (1964)

Muir. I.D., Tilley, D.E., Scoon, J.H.: Basalts from the northern part of the Mid-Atlantic Ridge. II Atlantis collections near $30^{\circ} \mathrm{N}$. J. Petrol. 7 (2), 193201 (1966)

Neadham. H.D.. Francheteau. J.: Some characteristics of the Rift Valley in the Atlantic Ocean near $36^{\circ} 48^{\prime}$ N. Earth Planet. Sci. Letters 22 (1), 29.43 (1974)

Nicholls. G.D.: Basalts from the deep ocean floor. Mineral. Mag. in Tilley volume. 373388 (1965)

Nicholls, C.D., Islam. M.R.: Geochimical investigations of basalts and associated rocks from the ocean floor and their implications. Phil. Trans. Roy. Soc. London A 268, 469486 (1971)

Noe-Nygaard, A.: The geology of the Faeroe's. Quart. J. (ieol. Soc. London 118. 375383 (1962)

Sigvaldason, G.E.: Chemistry of basalts from Icelandic rift zone, Contrib. Mineral. Petrol. 20, $357-370$ (1969)

Thompson, G., Bryan, W.B., Frey, F.A.. Sung. C.M.: Petrology and geochemistry of basalts and related rocks from sites $214,215,216$, DSDP leg 22, Indian ocean. In Initial Report, D.S.D.P. 22. 459-468 (1974)

Thompson, G., Melson. W (G. : The petrology of oceanic crust across fracture zones in the Atlantic ocean: evidence of a new kind of sea-floor spreading. J. (ieol. 80, 526-538 (1972)

Thompson, G., Shido. F.. Miyashiro, A. : Trace element distributıon in fractionated oceanic basalts. Chem. Geol. 9.8987(1971)

Thorasinsson, S., Steinthorsson. S., Einarsson. T., Kristmannsdottır. H.. ()skarsson, N.: The eruptıon on Heimaey Iceland. Nature 241, 372 -375 (1973)

Shibata, T., Fox. P.J. : Fractionation of Abyssal tholeittes. samples from the Oceanographer Fracture zone $\left(35^{\circ} \mathrm{N} 35^{\circ} \mathrm{W}\right)$. Earth Planet. Sci. Letters 27. 62. 72 (1975) 
Shido, F., Miyasshiro, A., Ewing, M.: Crystallization of abyssal tholeiites, Contrib. Mineral. Petrol. 31, 251-266 (1971)

Shido, F., Miyashiro, A., Ewing, M.: Compositional variation in pillow lavas from the Mid-Atlantic Ridge. Marine Geol. 16, 177-190 (1974)

Uchupi, I.: The Atlantic, Carribbean and Gulf of Mexico woods Hole Oceanographic Institution, ref. $\mathrm{n}^{\circ} 71-72(1971)$

White, W.M., Hart, S.R., Schilling, J.G.: Geochemistry of the Azores and the Mid-Atlantic Ridge: $29^{\circ} \mathrm{N}$ to $60^{\circ} \mathrm{N}$. Carnegie Inst. Yr. Book 74, $224234(1975)$

Yoder. H., Tilley, C.E.T.: Origin of basaltic magmas: synthetic rock system. J. Petrol. 3, 342-532 (1962)

Received April 9, 1976 / Accepted April 20, 1976

\section{Note Added in Proof}

The pyroxene basalt mentioned in the figure captions 2 and 5 corresponds to the plagioclase-pyroxene basalt type of rock described elsewhere (Arcyana. in press). 